\title{
HUKUM DAN ETIKA DALAM BERMEDIA SOSIAL
}

\section{Oleh: M. Jamil ${ }^{1}$}

Dewasa ini media sosial sudah melekat dalam diri hampir semua insan di dunia, demikian juga kondisi yang terjadi di Indonesia. Media sosial saat ini dipandang efektif dijadikan sarana untuk mempermudah komunikasi antara satu dengan yang lainnya. Berkaitan dengan komunikasi, saya ingat betul saat masamasa SMP dan SMA dengan kondisi susahnya berkomunikasi. Dulu, jika ingin berkomunikasi dengan kerabat yang berada di lain daerah kita harus kabarin lewat selebaran surat melalui Pos Indonesia, kalau tidak kita harus sempatkan waktu untuk menghampirinya langsung. Bila kita bandingkan dengan saat ini, mudah kita komunikasi dengan siapun, kapanpun dan dimapun yang kita inginkan, itu semata karena adanya media sosial.

Media sosial memiliki karakteristik yang berbeda dengan teknologi komunikasi lainnya. Beberapa karakteristik yang berbeda adalah updating (memperbarui) secara real-time (waktu sebenarnya), informasi yang tersebar secara luas, memiliki titik kumpul untuk melihat informasi, memiliki fitur yang memungkinkan pengguna situs media sosial dapat menanggapi dan memberi masukan (Monica Hidajat dkk, 2015: 80). Beberapa media sosial yang akhir-akhir ini populeh digunakan masyarakat adalah facebook, twitter, instagram, path, dan lain sebagainya.

Sosial media merupakan sebuah media untuk berkomunikasi atau bersosialisasi antara satu sama lain, dan dilakukan secara online yang memungkinkan kita bisa saling berinteraksi tanpa dibatasi ruang dan waktu.

Survei yang dilakukan sepanjang 2016 oleh Asosiasi Penyelenggara Jaringan Internet Indonesia (APJII) mengungkap lebih dari setengah penduduk

\footnotetext{
${ }^{1}$ Ketua Umum Pusat Studi Mahasiswa Pascasarjana (PUSMAJA) Mbojo-Yogyakarta Periode 2015-2017 | | Ketua II Bagian Eksternal Dewan Pimpinan Cabang Perhimpunan Mahasiswa Hukum Indonesia Daerah Istimewa Yogyakarta (DPC PERMAHI DIY) Periode 2012-2014 | Email: jamilncera@gmail.com | FB/Youtube/IG/Twitter: @MJAMILSH | Website: http://www.mjamil.my.id.
} 
Indonesia telah terhubung ke internet. Total penduduk Indonesia sebanyak 256,2 juta jiwa, sebanyak 132,7 juta orang telah terhubung ke internet (Yoga Hastyadi Widiartanto, 08/08/2017). Itu membuktikan animo masyarakat akan bermedia sosial melalui internet sangatlah tinggi. Tidak tanggung-tanggung, malah saat ini pemerintah Indonesia melalui Menteri Komunikasi dan Informatika, Rudiantara menargetkan dan sangat optimistis bahwa pada tahun 2019 nanti, perluasan jaringan telekomunikasi seluruh kabupaten kota di wilayah Indonesia sudah terjangkau oleh jaringan internet (Nur Islami, kominfo.go.id, 08/08/2017). Kalau ini benar-benar terjadi, paling tidak minimal dapat mempermudah pelayanan masyarakat disetiap jenjang pelayanan pemerintahan.

Mengingat begitu pentingnya ruang dalam berinteraksi melalui media sosial, maka dipandang perlu adanya etika serta aturan yang mengatur secara legal formal, agar tatanan sosial yang terjalin didalamnya juga dapat teratur tanpa adanya kesewenang-wenangan dalam berkomunikasi.

Karena sebab kegelisahan diatas, pada tahun 2008 pemerintah menerbitkan undang-undang yang mengatur tentang bagaimana pengaturan hukum perihal informasi dan transaksi elektronik, termasuk didalamnya berinteraksi dalam media sosial, yakni dalam Undang-Undang Republik Indonesia Nomor 11 Tahun 2008 Tentang Informasi dan Transaksi Elektronik (UU ITE). Selang 8 tahun berlaku, UU ITE terakhir diperbarui pada tahun 2016 melui UU Nomor 19 Tahun 2016 Tentang Perubahan Atas Undang-Undang Nomor 11 Tahun 2008 Tentang Informasi dan Transaksi Elektronik.

Hadirnya UU ITE tersebut, untuk menjamin pengakuan serta penghormatan atas hak dan kebebasan orang lain dan untuk memenuhi tuntutan yang adil sesuai dengan pertimbangan keamanan dan ketertiban umum dalam suatu masyarakat yang demokratis agar terwujud keadilan, ketertiban umum, dan kepastian hukum di tatanan kehidupan bermasyarakat, berbangsa dan bernegara.

Media sosial seyogyanya dapat menjadi wahana untuk mendudukkan proses dialog yang sehat dalam berkomunikasi agar terwujud harmonis. Media sosial sejatinya menempatkan proses dialog dalam berkomunikasi dan menciptakan 
ruang untuk menciptakan diseminasi gagasan secara rasional dan menyejukkan (Uud Wahyudin dan Kismiyati El Karimah, 2016: 217).

Untuk menjaga keteraturan dalam berkomunikasi dan berinteraksi dalam media sosial, sangat perlu menjaga serta menjunjung tinggi nilai-nilai etika serta sopan santun dalam setiap berinteraksi.

Sebagai suatu upaya untuk mencegah komunikasi yang tidak sehat serta menjunjung tinggi etika dalam berkomunikasi via media sosial, baiknya sebelum menyebarkan informasi atau sebelum berkomunikasi, kita perlu melakukan pengecekan dan verifikasi terlebih dahulu informasi tersebut, apakah informasi atau apa yang ingin kita sampaikan layak atau perlu kita sampaikan, dalam artian tidak menyalahi etika dan tentunya tidak menyalahi norma serta peraturan perundang-undangan yang berlaku, karena rakyat biasa atau rakyat berdasi, bahkan penguasa diperlakukan sama dihadapan hukum (equality before the law) dianggap tahu hukum, dan tidak bisa menyangkal akan ketidaktahuannya tentang hukum.

Selain itu, kita juga perlu memperhatikan bahasa yang dipergunakan untuk berkomunikasi di media sosial. Perlu kita menjunjung tinggi proses edukasi serta penerapan disiplin diri terhadap orang lain dalam setiap berinteraksi. Apalagi pergaulan dan tata cara berkomunikasi remaja dewasa ini sudah sangat terbuka dan dipermudah dengan adanya media sosial. Oleh karena itu, perlu campur tangan yang lainnya untuk pencegahan, yakni dengan adanya bimbingan orang tua (selama di lingkup kelurga), sekolah (dengan bantuan guru atau tenaga pendidik), universitas (dengan bntuan dosen atau tenaga pengajar), serta lingkungan masyarakat bila berada di luar jangkauan orang tua.

Bila melirik penjelasan umum dalam UU Nomor 19 Tahun 2016 tentang ITE, digambarkan bahwasannya, dalam kehidupan bermasyarakat, berbangsa, dan bernegara, hak dan kebebasan melalui penggunaan dan pemanfaatan Teknologi Informasi dilakukan dengan mempertimbangkan pembatasan yang ditetapkan dengan undang-undang dengan maksud semata-mata untuk menjamin pengakuan serta penghormatan atas hak dan kebebasan orang lain dan untuk memenuhi tuntutan yang adil sesuai dengan pertimbangan moral, nilai-nilai agama, 
"Hukum dan Etika dalam Bermedia Sosial"

keamanan, dan ketertiban umum dalam suatu masyarakat demokratis. Jadi, etika dalam berkomunikasi di media sosial mutlak harus di jaga. Apalagi dalam pandangan agama, lebih-lebih agama Islam, menjaga etika, sopan santun itu merupakan suatu keharusan dalam berinteraksi, agar kita tergolong insan yang kamil, karena berlandaskan nilai-nilai yang terkandung dalam Al-Qur'an dan Hadis.

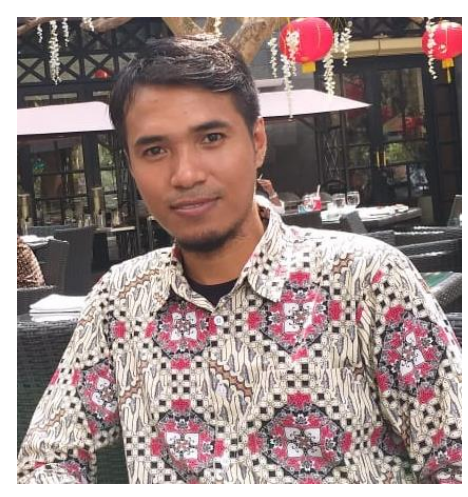

Penulis: M. Jamil, S.H.

Ketua Umum Pusat Studi Mahasiswa Pascasarjana (PUSMAJA) Mbojo-Yogyakarta Periode 2015-2017 | Ketua II Bagian Eksternal Dewan Pimpinan Cabang Perhimpunan Mahasiswa Hukum Indonesia Daerah Istimewa Yogyakarta (DPC PERMAHI DIY) Periode 2012-2014.

\section{Ful Sumber Tulisan:}

M. Jamil, "Hukum dan Etika dalam Bermedia Sosial", Majalah NUSANTARA IKPMDI-Yogyakarta, diterbitkan melalui Dinas Pendidikan Pemuda dan Olahraga (Disdikpora) Daerah Istimewa Yogyakarta, edisi Juli-Agustus 2017, lihat Halaman 19-20. 